\title{
Study on the Economics of Banana Cultivation under Drip Fertigation
}

\author{
T. Basanta Singh ${ }^{1 *}$, S.K. Patra ${ }^{1}$, K.H. Rishikanta Singh ${ }^{2}$ and Chongtham Tania ${ }^{2}$ \\ ${ }^{1}$ Bidhan Chandra Krishi Viswavidyalaya, Mohanpur-741252, West Bengal, India \\ ${ }^{2}$ ICAR Research Complex for NEH Region, Manipur Centre, \\ Lamphelpat -795004, Imphal, India \\ *Corresponding author
}

\section{A B S T R A C T}

\begin{tabular}{|l|}
\hline K e y w o r d s \\
$\begin{array}{l}\text { Economics, Drip } \\
\text { fertigation, Banana } \\
\text { cultivation }\end{array}$ \\
\hline Article Info \\
\hline $\begin{array}{l}\text { Accepted: } \\
\text { 22 October } 2018 \\
\text { Available Online: } \\
\text { 10 November } 2018\end{array}$ \\
\hline
\end{tabular}

\section{Introduction}

Banana is one of the leading fruit crop of India. In India, drip fertigation is extensively used in the banana cultivation. This microirrigation system also allows clean and mechanized cultivation, thereby substantially reducing the cost of weeding. The potential for drip irrigation system in India is estimated to be around 21.3 $\mathrm{M}$ ha (Narayanamoorthy, 2008). But till the year 2010, we could achieve $1.9 \mathrm{~m}$ ha only under drip (4.9 $\mathrm{M}$ ha in micro irrigation). It has been accepted as the best solution for intensive crop production (Samuel et al., 2002) and maintenance of economic viability through increased water use efficiency and water saving (Narayanamoorthy, 2006). The farmers in India generally follow conventional surface method of irrigation in banana cultivation which is quite inefficient and nonremunerative. The major portion of cost is incurred in hiring labour for irrigation (More et al., 2005) and the drip fertigation system has been reported to reduce the labour costs by 30-35\% (Berad et al., 1999). The water saving, increase in productivity and gross income due to drip over the conventional flood method of irrigation in banana may be 29 percent, 29.1 percent and 30.2 percent, 
respectively with a BCR of 2.3 (Narayanamoorthy, 2003). The Horticulture Mission Project under the Government of India in collaboration with the state governments has implemented and adopted the exclusive programme of micro-irrigation with the subsidy to the extent of 50 percent, but many states are lagging behind on large scale implementation. Hence, there is need to encourage farmers to adopt the drip irrigation method, even the initial capital is high but labour saving at long run. The banana farmers are being constrained with technical expertise to adopt drip irrigation system otherwise the investment in the drip system may not yield a result. It has been observed that the investments in drip fertigation for sugarcane, banana and grape cultivation, the BCR with different discount rates remain economically viable. But, the banana farmers are being constrained with technical expertise to adopt drip irrigation system. Therefore, we have a great scope for experimentation, economic evaluation for drip fertigation practice in banana cultivation to give clear picture to the farmers.

\section{Materials and Methods}

The field experiment was conducted during the year 2012 and 2013 at the Central Research Farm, Gayeshpur, Bidhan Chandra Krishi Viswavidyalaya West Bengal encompassing the New Alluvial Zone $(9.75 \mathrm{~m}$ above MSL and $23^{\circ} \mathrm{N}$ and $89^{\circ} \mathrm{E}$ coordinate). Healthy sword suckers (2-3 leaf) weighing around $1.5-2 \mathrm{~kg}$ each (2.0-2.5 month old) of banana cv. Martaman (AAB group) were planted (spacing $=2 \mathrm{~m} \times 2 \mathrm{~m}$ ) in the square pattern. The ratoon was maintained by retaining only one sucker per plant. The reference crop evapotranspiration (ETo) was taken as the basis to calculate of crop water requirement (Doorenbos and Pruitt, 1977). The volume of water required per plot was computed based on the equation given by
Vermeiren and Jobling (1980). The drip fertigation was done at four evapotranspiration (ET) based irrigation levels $\left(\mathrm{D}_{1}=0.6 \mathrm{ET}\right.$, $\mathrm{D}_{2}=0.8 \mathrm{ET}, \mathrm{D}_{3}=1.0 \mathrm{ET}$ for drip and surface irrigation (S) at IW/CPE 1.0) and at three fertilizer levels of recommended doses of fertilizer (RDF) viz., $\mathrm{F}_{1}=60 \% \mathrm{RDF}, \mathrm{F}_{2}=80 \%$ RDF and $\mathrm{F}_{3}=100 \%$ RDF laid out in factorial randomized block design with three replications. In case of surface irrigation, water was applied at irrigation water (IW) divided by Cumulative pan evaporation (IW/CPE) equal to 1.0 which is scheduled at 15-20 days' interval. The water soluble and cheaply available conventional fertilizers were used for the fertigation.

\section{Economic analysis}

The economic analysis was carried out to determine the economic feasibility of the crop under standard drip fertigation vis-à-vis the surface irrigation with conventional soil fertilization assuming that the gravity drip gives approximately similar yield with the standard one. For the economic analysis (per hectare basis), total cost of cultivation, gross returns and net returns were calculated from the yield of banana (2500 plants/ha). The seasonal cost of drip irrigation system and 4 Horse Power water pump includes 4percent depreciation, prevailing 10 percent interest rate, 2 percent interest for repair and maintenance cost calculated from the fixed cost. The life span of the drip irrigation system was considered to be 10 years. The total cost of cultivation for drip and surface irrigations was calculated by considering the cost incurred in land preparation, intercultural operation, fertilizer, crop protection measures, irrigation water and harvesting during the period of experimentation. Gross return from each treatment was calculated from the yield of banana by accounting the prevailing market price during the harvesting periods. Net returns were calculated by subtracting the total 
cost of cultivation from the gross return. The benefit cost ratio (BCR) was calculated by dividing the gross returns of each treatment with their respective cost of cultivations.

\section{Results and Discussion}

The economics of the drip fertigation systems was worked out to determine the economic feasibility and benefit-cost ratio of the system by considering the cost of standard drip fertigation vis-à-vis the surface irrigation with soil fertilization assuming that the gravity drip delivers approximately similar yield with the standard one. The seasonal system cost of drip irrigation system incorporates depreciation, prevailing bank interest rate and repair and maintenance cost of the system. The depreciation was taken as 4 percent, the interest rate as 10 percent and repair as well as maintenance cost of the system as 2 percent per annum of the fixed cost.

The usual life span of the drip system was considered to be 10 years. The operating cost of cultivation accommodated expenses incurred in land preparation and planting, intercultural operation, fertilizers, crop protection measures, irrigation water and harvesting with labour charges. The total cost of banana cultivation was determined by adding the fixed cost and operating cost of cultivation including the different treatments cost. The estimated seasonal cost of cultivation excluding the variable cost of fertilizers and irrigation was observed to be Rs. 82,500 for the drip irrigation system and Rs. 76,500 for the surface irrigation system (Table 1). The total average volume of water required to irrigate 1.0 ha of banana field constituting 2500 plants $(2 \mathrm{~m} \times 2 \mathrm{~m})$ through drip irrigation system was found to be 2386.2 $\mathrm{m}^{3}$ for 0.6 ETo, $3181.6 \mathrm{~m}^{3}$ for 0.8 ETo and $3977.0 \mathrm{~m}^{3}$ for 1.0 ETo considering 90 percent irrigation efficiency and $9600.0 \mathrm{~m}^{3}$ for surface irrigation system at IW/CPE 1.0 considering
75 percent irrigation efficiency. The treatment costs of irrigation and fertilizer for drip fertigation ranged between Rs. 17,663 to Rs. 29,438/ha/year and Rs. 23,675 to Rs. $34,124 /$ ha/year for surface irrigation plus soil fertilization (Table 2).

The gross return of each treatment was calculated by multiplying the yield of banana with the prevailing market price @ Rs. 11/kg during the harvesting periods i.e., March and April of 2012 and 2013 (Table 3). Gross return was observed to be the highest for the treatment combination $\mathrm{D}_{3} \mathrm{~F}_{3}$ (Rs. 478958/ha/year), followed by the treatment combination $\mathrm{D}_{2} \mathrm{~F}_{3}$ (Rs. 475750/ha/year) and $\mathrm{D}_{2} \mathrm{~F}_{2}$ (Rs. 468875/ha/year). However, the lowest gross return of Rs. 248417/ha/year was obtained from surface irrigation supplemented with $60 \%$ of $\mathrm{RDF}\left(\mathrm{SF}_{1}\right)$. It was also observed that the net return from drip system at varying levels of irrigation and fertigation was found to be higher in all cases than the surface method of irrigation except for $\mathrm{D}_{1} \mathrm{~F}_{1}$ treatment.

Out of the different drip fertigation treatments, drip irrigation at 1.0 ETo with $100 \%$ RDF $\left(\mathrm{D}_{3} \mathrm{~F}_{3}\right)$ recorded the highest net profit (Rs. 367,020/ha/year), immediately followed by that of drip irrigation at 0.80 ETo with $100 \%$ RDF $\left(\mathrm{D}_{2} \mathrm{~F}_{3}\right)$ exhibiting Rs. 364,474/ha/year and drip irrigation at 0.80 ETo with $80 \% \mathrm{RDF}$ $\left(\mathrm{D}_{2} \mathrm{~F}_{2}\right)$ showing a net profit of Rs. 362,842 /ha/year.

The BCR or return per rupee investment was found to be higher in drip fertigation treatments than that of conventional surface irrigation system (Table 3). The highest BCR was recorded for the treatment combination $\mathrm{D}_{2} \mathrm{~F}_{2}$ (4.42) followed by $\mathrm{D}_{2} \mathrm{~F}_{3}$ (4.28), $\mathrm{D}_{3} \mathrm{~F}_{3}$ (4.28) and $\mathrm{D}_{3} \mathrm{~F}_{2}$ (4.20) and for conventional method (2.48 to 3.40). The higher BCR in the drip fertigation was the consequences of the reduction of cost on irrigation and labour. 
Table.1 Fixed and operation cost of banana cultivation for one hectare of land under drip fertigation and surface irrigation systems (excluding fertilizer and irrigation cost)

\begin{tabular}{|c|c|c|c|}
\hline $\begin{array}{l}\text { Sl. } \\
\text { No. }\end{array}$ & Particular & $\begin{array}{l}\text { Drip } \\
\text { fertigation }\end{array}$ & $\begin{array}{l}\text { Surface } \\
\text { irrigation }\end{array}$ \\
\hline \multicolumn{4}{|c|}{ Fixed cost } \\
\hline 1 & $\begin{array}{l}\text { Installation cost including one } 4 \mathrm{HP} \text { water pump } \\
\text { (Rs. 20,000) }\end{array}$ & 1,00000 & - \\
\hline 2 & Life span for drip system and water pump (year) & 10 & - \\
\hline 3 & Depreciation@4\% (Rs.) & 4,000 & - \\
\hline 4 & Interest cost @ 10\% (Rs.) & 10,000 & - \\
\hline \multicolumn{4}{|c|}{ Operating cost (excluding fertilizers and irrigation cost) } \\
\hline 5 & $\begin{array}{l}\text { Repair and maintenance cost including electrical } \\
\text { and labour charge @ 2\% (Rs.) }\end{array}$ & 2000 & - \\
\hline 6 & Seasonal cost of drip system $(3+4+5)$ (Rs.) & 16,000 & - \\
\hline 7 & Cost for field preparation and planting (Rs.) & 30,000 & 30,000 \\
\hline 8 & Cost for cultural practices (Rs.) & 25,000 & 35,000 \\
\hline 9 & $\begin{array}{l}\text { Cost for plant protection measures i.e., chemicals + } \\
\text { application charges (Rs.) }\end{array}$ & 6,500 & 6,500 \\
\hline \multirow[t]{2}{*}{10} & $\begin{array}{l}\text { Labour cost incurred during harvesting @ Rs. } \\
\text { 2/bunch }\end{array}$ & 5,000 & 5,000 \\
\hline & Seasonal total cost $(6+7+8+9+10)$ & Rs. 82,500 & Rs. 76,500 \\
\hline
\end{tabular}


Table.2 Details of treatment cost for fertilizers and irrigation for cultivating one hectare of banana

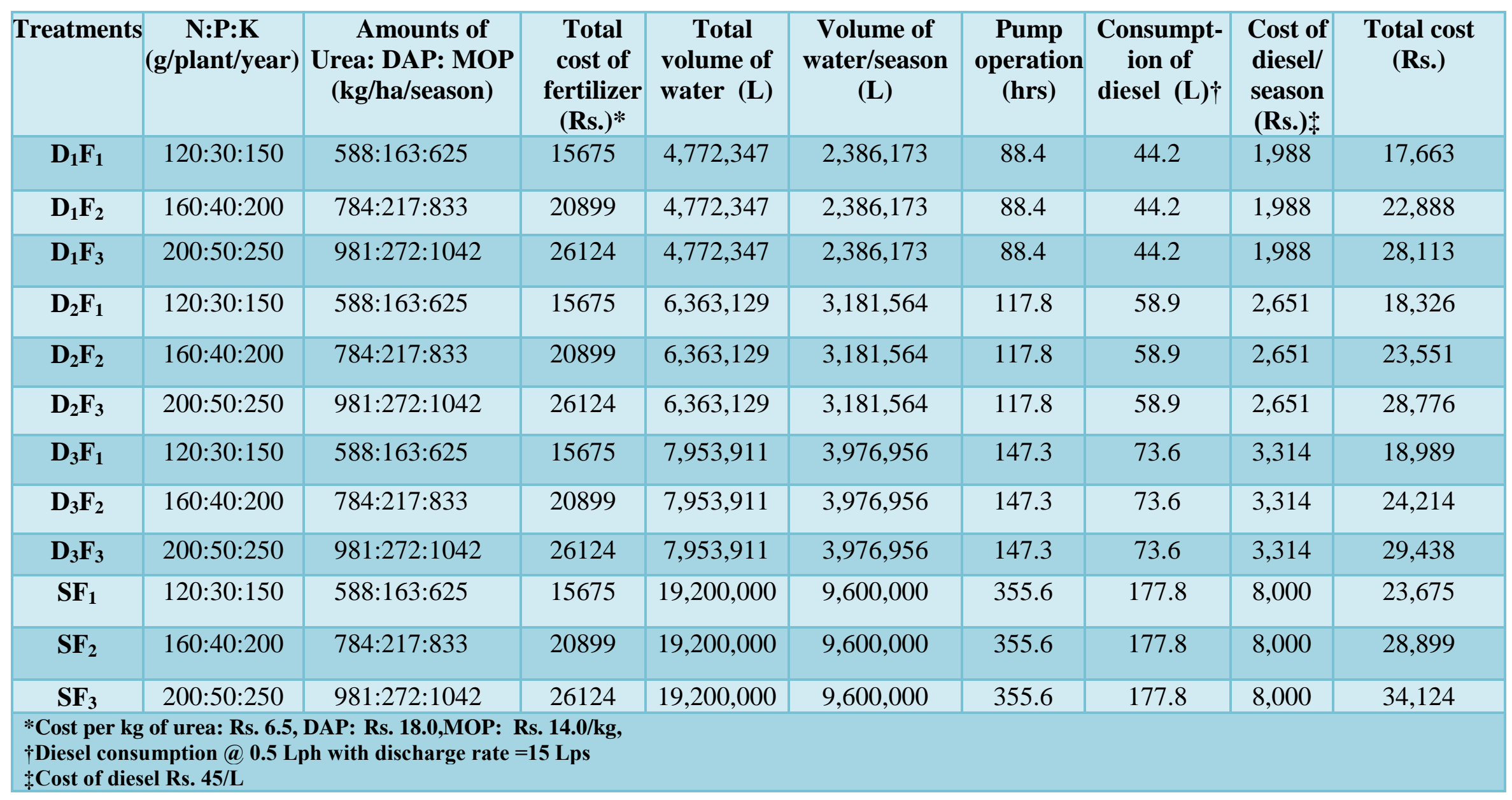


Table.3 Economic analysis of different treatment combinations in banana cultivation for one hectare of land

\begin{tabular}{|c|c|c|c|c|c|c|c|}
\hline Treatments & $\begin{array}{c}\text { Fixed and } \\
\text { operating cost of } \\
\text { cultivation (Rs. } \\
\text { /ha) } \dagger\end{array}$ & $\begin{array}{l}\text { Fertilizers and } \\
\text { irrigation cost } \\
\text { (Rs. /ha) }\end{array}$ & $\begin{array}{l}\text { Seasonal total } \\
\text { cost of } \\
\text { Cultivation } \\
\text { (Rs. /ha) }\end{array}$ & Yield (t/ha) & $\begin{array}{c}\text { Gross } \\
\text { returns (Rs. } \\
\text { /ha)* }\end{array}$ & $\begin{array}{l}\text { Net returns } \\
\text { (Rs. /ha) }\end{array}$ & $\begin{array}{c}\text { Benefit cost } \\
\text { ratio } \\
\text { (BCR) }\end{array}$ \\
\hline $\mathbf{D}_{1} \mathbf{F}_{1}$ & 82,500 & 17,663 & 100,163 & 28.2 & 310,292 & 210,129 & 3.10 \\
\hline$D_{1} F_{2}$ & 82,500 & 22,888 & 105,388 & 35.5 & 390,042 & 284,654 & 3.70 \\
\hline$D_{1} F_{3}$ & 82,500 & 28,113 & 110,613 & 38.3 & 421,667 & 311,054 & 3.81 \\
\hline $\mathbf{D}_{2} \mathbf{F}_{1}$ & 82,500 & 18,326 & 100,826 & 34.8 & 382,250 & 281,424 & 3.79 \\
\hline $\mathbf{D}_{2} \mathbf{F}_{2}$ & 82,500 & 23,551 & 106,051 & 42.6 & 468,875 & 362,824 & 4.42 \\
\hline $\mathbf{D}_{2} \mathbf{F}_{3}$ & 82,500 & 28,776 & 111,276 & 43.3 & 475,750 & 364,474 & 4.28 \\
\hline $\mathrm{D}_{3} \mathrm{~F}_{1}$ & 82,500 & 18,989 & 101,489 & 38.0 & 417,542 & 316,053 & 4.11 \\
\hline $\mathbf{D}_{3} \mathbf{F}_{2}$ & 82,500 & 24,214 & 106,714 & 40.8 & 448,708 & 341,995 & 4.20 \\
\hline $\mathbf{D}_{3} \mathbf{F}_{3}$ & 82,500 & 29,438 & 111,938 & 43.5 & 478,958 & 367,020 & 4.28 \\
\hline $\mathrm{SF}_{1}$ & 76,500 & 23,675 & 100,175 & 22.6 & 248,417 & 148,242 & 2.48 \\
\hline $\mathrm{SF}_{2}$ & 76,500 & 28,899 & 105,399 & 30.3 & 332,750 & 227,351 & 3.16 \\
\hline $\mathbf{S F}_{3}$ & 76,500 & 34,124 & 110,624 & 34.2 & 375,833 & 265,209 & 3.40 \\
\hline
\end{tabular}


Similar findings have been reported by Chandrakumar et al., (2001) who recorded the highest BCR was with $150 \mathrm{~g} / \mathrm{plant} /$ year of $\mathrm{N}$ and $\mathrm{K}$ fertigation in banana. The BCR of 5.26 has been demonstrated from drip fertigation of banana in Bhawansinagar, Gujarat (AICRP-WM, 2010). More et al., (2005) demonstrated that the major portion of human labour was chiefly used for irrigating the crop leading to the reduction of BCR which was drastically curtailed in drip irrigation system. Increased income in banana crop through drip irrigation has also been reported earlier (Agrawal and Agrawal, 2005; Shashidhara et al., 2007). Based on the higher average WUE (55.7 kg/ha-mm), average water saving $(49.8 \%)$ and a higher estimated BCR (4.42), the drip irrigation at $80 \%$ evapotranspiration replenishment (0.8 ETo) equivalent to 3181.5 $\mathrm{m}^{3} / \mathrm{ha} /$ year or 1272.6 litre/plant/year supplemented with $80 \%$ RDF (N:P:K $=160: 40: 200 \mathrm{~g} / \mathrm{plant} / \mathrm{year}$ ) can be advocated to the farmers of Gangetic plain of India.

From the results of the study, it can be concluded that, drip irrigation is by far the most advantageous over conventional surface irrigation in economizing water use in terms of higher water use efficiency and considerable water savings with higher yield of banana. Though the initial investment for laying the drip fertigation system is high and an impediment for resource poor farmers, however, its long-term benefits can be accrued by increasing the monetary returns and hence improving the better economy of small and marginal farmers. Farmers can opt for low cost and easily available fertilizers like urea, DAP, and MOP. The future of the banana cultivation practice in 21 st century lies in the use of fertigation method through drip irrigation.

\section{Acknowledgement}

The authors are thankful to Department of Soil Science and Agricultural Chemistry,
Bidhan Chandra Krishi Viswavidyalaya, Mohanpur, West Bengal for providing the facility and technical support to carry out this field experiment.

\section{References}

Berad, S. M, Shinde, S. H. and Dahiwalkar, S. D. 1999. Effects of drip fertigation and paired planting on productivity and economics of banana. Journal of Maharashtra Agricultural Universities 23(3); 288-290.

Doorenbos, J. and Pruitt, W. O. 1977. Crop water requirement. Irrigation and Drainage Paper No. 24, FAO, Rome.

More, S. S., Shelke, R. D. and Kalyankar, S.P. 2005. Labour utilization and input use pattern in banana cultivation. Agricultural Marketing 48(1); 21 -23.

Narayanamoorthy, A. 2006. Efficiency of irrigation: a case of drip irrigation. Occasional Paper National Bank for Agriculture and Rural Development, Mumbai 45, 38.

Narayanamoorthy, A. 2003. Averting water crisis by drip method of irrigation: a study of two water-intensive crops. Indian Journal of Agricultural Economics 58(3); 427-437.

Narayanamoorthy, A. 2008. Drip irrigation in India: can it solve water scarcity? Water Policy. 6, 117-130.

Samuel, J. C. and Singh, H. P. 2002. Perspective of Hi-tech horticulture and precision farming. In- Proceedings National Seminar -cum- workshop on Hi-tech Horticulture and Precision Farming (Eds. Singh, H.P. et al.,). CISH, Lucknow. pp. 21-34.

Vermeiren, I. and Jobling, G. A. 1980. Localized irrigation design, installation, operation and evaluation. Irrigation and Drainage Paper No. 36, FAO, Rome. 10-12.

Chandrakumar, S. S., Thimmegowda, S., Srinivas, K. Reddy, B. M. C. and 
Devakumar, N. 2001. Performance of Robusta banana under nitrogen and potassium fertigation. South Indian Horticulture 49(Sp.); 92-94.

AICRP-WM (All India Coordinated Research Project on Water management), 2010. Annual Report 2009-2010. Directorate of Water Management, ICAR, Bhubaneswar, Orissa. P. 248.

Agrawal, N. and Agrawal, S. 2005. Effect of drip irrigation and mulches on the growth and yield of banana cv. Dwarf Cavendish. Indian Journal of Horticulture 62, 238-240.

Shashidhara, K. K., Bheemappa, A., Hirevenkanagoudar, L. V. and Shashidhar, K. C. 2007. Benefits and constraints in adoption of drip irrigation among the plantation crop growers. Karnataka Journal of Agricultural Sciences 20, 82-84.

\section{How to cite this article:}

Basanta Singh, T., S.K. Patra, K.H. Rishikanta Singh and Chongtham Tania. 2018. Study on the Economics of Banana Cultivation under Drip Fertigation. Int.J.Curr.Microbiol.App.Sci. 7(11): 2628-2635. doi: https://doi.org/10.20546/ijcmas.2018.711.300 